\title{
Production of Agrocinopine A by Ipomoea batatas Agrocinopine Synthase in Transgenic Tobacco and Its Effect on the Rhizosphere Microbial Community
}

\author{
Aiko Tanaka, ${ }^{1}$ Maarten H. Ryder, ${ }^{2}$ Takamasa Suzuki, ${ }^{3}$ Kazuma Uesaka, ${ }^{4}$ Nobuo Yamaguchi, ${ }^{5}$ \\ Tomoko Amimoto, ${ }^{6}$ Motoyasu Otani, ${ }^{7}$ Osamu Nakayachi, ${ }^{7}$ Kenji Arakawa, ${ }^{8}$ Nobukazu Tanaka, ${ }^{5, \dagger}$ and \\ Daigo Takemoto ${ }^{1, \dagger}$ \\ ${ }^{1}$ Graduate School of Bioagricultural Sciences, Nagoya University, Chikusa, Nagoya, Aichi 464-8601, Japan \\ ${ }^{2}$ School of Agriculture, Food \& Wine, The University of Adelaide, Glen Osmond, South Australia 5064, Australia \\ ${ }^{3}$ College of Bioscience and Biotechnology, Chubu University, Kasugai, Aichi 478-8501, Japan \\ ${ }^{4}$ Center for Gene Research, Nagoya University, Chikusa, Nagoya, Aichi 464-8602, Japan \\ ${ }^{5}$ Natural Science Center for Basic Research and Development, Hiroshima University, Higashi-Hiroshima, Hiroshima 739-8527, \\ Japan \\ ${ }^{6}$ Natural Science Center for Basic Research and Development, Hiroshima University, Higashi-Hiroshima, Hiroshima 739-8526, \\ Japan \\ ${ }^{7}$ Research Institute for Bioresources and Biotechnology, Ishikawa Prefectural University, Ishikawa 921-8836, Japan \\ ${ }^{8}$ Graduate School of Integrated Sciences for Life, Hiroshima University, Higashi-Hiroshima, Hiroshima 739-8530, Japan
}

Accepted 29 September 2021.

Agrobacterium tumefaciens is a bacterial pathogen that causes crown gall disease on a wide range of eudicot plants by genetic transformation. Besides T-DNA integrated by natural transformation of plant vegetative tissues by pathogenic Agrobacterium spp., previous reports have indicated that T-DNA sequences originating from an ancestral Agrobacterium sp. are present in the genomes of all cultivated sweet potato (Ipomoea batatas) varieties analyzed. Expression of an Agrobacterium-derived agrocinopine synthase (ACS) gene was detected in leaf and root tissues of sweet potato, suggesting that the plant can produce agrocinopine, a sugar-phosphodiester opine considered to be utilized by some strains of Agrobacterium spp. in crown gall. To validate the product synthesized by Ipomoea batatas ACS (IbACS), we introduced IbACS into tobacco under a constitutive promoter. High-voltage paper electrophoresis followed by alkaline silver nitrate staining detected the production of an agrocinopine-like substance in IbACS1-expressing tobacco, and further mass spectrometry and nuclear magnetic resonance analyses of the product confirmed that IbACS can produce agrocinopine A from natural plant substrates. The partially purified compound was biologically active in an agrocinopine A bioassay. A $16 \mathrm{~S}$ ribosomal

${ }^{\dagger}$ Corresponding authors: D. Takemoto; dtakemo@agr.nagoya-u.ac.jp and N. Tanaka; ntana@hiroshima-u.ac.jp

Funding: This work was supported by the Japan Society for the Promotion of Science through a Grant-in-Aid for Challenging Exploratory Research (number 18K19209).

*The $\boldsymbol{e}$-Xtra logo stands for "electronic extra" and indicates there are supplementary materials published online.

The author(s) declare no conflict of interest. distributed under the CC BY-NC-ND 4.0 International license.
RNA amplicon sequencing and meta-transcriptome analysis revealed that the rhizosphere microbial community of tobacco was affected by the expression of IbACS. A new species of Leifsonia (actinobacteria) was isolated as an enriched bacterium in the rhizosphere of IbACSI-expressing tobacco. This Leifsonia sp. can catabolize agrocinopine A produced in tobacco, indicating that the production of agrocinopine $A$ attracts rhizosphere bacteria that can utilize this sugarphosphodiester. These results suggest a potential role of IbACS conserved among sweet potato cultivars in manipulating their microbial community.

Keywords: Agrobacterium tumefaciens, agrocinopine synthase, bacteria-plant symbiosis, Ipomoea batatas, sweet potato

Agrobacterium species, such as A. tumefaciens, A. rhizogenes, and $A$. vitis, have mechanisms for active horizontal gene transfer (HGT) from bacteria to plant cells. Virulent strains of these pathogens possess a large $\mathrm{Ti}$ (tumor-inducing) or $\mathrm{Ri}$ (rootinducing) plasmid, which contains the vir (virulence) genes for the DNA transfer, and genes to be transferred to genomic DNA of the host plant (T-DNA). T-DNA includes genes for the biosynthesis of plant growth regulators (auxins and cytokinins) to induce neoplastic growths (crown galls and adventitious hairy roots) and enzymes involved in the synthesis of opines. Opines include secondary amine derivatives (e.g., nopaline and octopine) and sugar-phosphodiesters (agrocinopines), which can be utilized by Agrobacterium strains harboring the corresponding catabolic genes as a source of carbon, nitrogen, and phosphorus. Generally, genes introduced by Agrobacterium strains are not inherited by the next generation of the infected host plant. However, previous reports have indicated that T-DNA sequences are found in the genomes of a wide range of plant species, including Nicotiana (e.g., tobacco), Camellia (tea), Arachis (peanut), and Ipomoea (sweet potato) species, and these sequences are referred to as cellular T-DNA (cT-DNA) (Kyndt et al. 2015; 
Matveeva and Otten 2019; Matveeva and Sokornova 2017; White et al. 1983).

Sweet potato [Ipomoea batatas (L.) Lam.] is one of the most important and widely consumed crops. The cultivated sweet potato is a hexaploid species with 90 chromosomes $(2 n=6 x=$ 90). Genome sequence analysis of the diploid wild relative $I$. trifida has revealed that I. trifida is the most probable diploid relative of I. batatas (Hirakawa et al. 2015). Two cT-DNAs, IbT-DNA1 and IbT-DNA2, have been discovered in the sweet potato cultivar Huachano and in 290 other cultivars (Kyndt et al. 2015). IbT-DNA sequences have also been found in the genomes of other Ipomoea species (I. trifida, I. cordatotriloba, and I. tenuissima) (Quispe-Huamanquispe et al. 2019), indicating that a common ancestral Ipomoea species obtained T-DNA that entered the host germline and T-DNA was retained in descendant species. IbT-DNA1 contains four coding sequences, namely, agrocinopine synthase (ACS), C-protein, indoleacetamide hydrolase $(\mathrm{iaaH})$, and tryptophan monooxygenase (iaaM) (Kyndt et al. 2015; Quispe-Huamanquispe et al. 2019). Expression of cT-DNA genes has been detected in various tissues of cultivated sweet potato (Kyndt et al. 2015), suggesting that genes in the IbT-DNA region might have a function in Ipomoea species.

In this study, we focused on the activity of the ACS gene IbACS1 in plants. Agrocinopines are sugar-phosphodiesters and, for instance, agrocinopine A is composed of sucrose linked to L-arabinose via a phosphodiester bond (Ryder et al. 1984). Inciting Agrobacterium strains have an operon encoding enzymes for agrocinopine assimilation on the Ti plasmid, including genes for a sugar $\mathrm{ABC}$ transporter and enzymes for sugar-phosphate catabolism (Hayman and Farrand 1988; Hayman et al. 1993; Kim and Farrand 1997). Thus, it was expected that agrocinopines would be utilized by a limited range of bacteria. To detect the activity of IbACS in plants, the IbACS gene was heterologously expressed in tobacco under the control of a constitutive promoter, and the substance produced by IbACS was identified. We have also examined the effect of IbACS expression on the rhizosphere microbial community of tobacco and discussed the potential role of sweet potato IbACS in plantmicrobial interactions.

\section{RESULTS}

\section{Analysis of T-DNA region in the genome of Ipomoea batatas cv. Hanaranman.}

Previous studies indicated that genomes of Ipomoea species, including cultivated sweet potato I. batatas, contain T-DNA sequences IbT-DNA1 and IbT-DNA2, derived from (possibly extinct) species related to A. rhizogenes (Kyndt et al. 2015). In this study, we first assessed T-DNA sequences in Japanese sweet potato cultivar Hanaranman. Two fragments corresponding to the partial sequence of IbT-DNA1, IbT-DNA1_A and IbT-DNA1_B, were PCR-amplified from cultivar Hanaranman and were sequenced (Fig. 1A). Four intact coding sequences, ACS1 (IbACS1), C-protein1, iaaH1, and iaaM1 were identified in IbT-DNA1_A, while two coding sequences, IbiaaH2 and $C$ protein2, and a second sequence homologous to ACS (IbACS2) with an internal stop codon were found in IbT-DNA1_B. As previously reported for different cultivars (Kyndt et al. 2015), expression of IbACS1 was detected in leaf and root tissues of cultivar Hanaranman (Fig. 1B).

A phylogenetic analysis of the IbACS1 protein sequence was carried out with ACS proteins from Agrobacterium species, including ACS1 from A. tumefaciens C58, which is responsible for the production of agrocinopine A (phosphodiester of sucrose and L-arabinose) and ACS from A. tumefaciens Bo542, which codes for agrocinopine C (phosphodiester of sucrose and D-glucose) production (Ellis and Murphy 1981; Joos et al. 1983; Oger and Farrand 2001). The phylogenetic tree formed two major branches, showing that ACS genes can be divided into two major groups (Supplementary Fig. S1). Group 1 includes Agrobacterium ACS1 (including ACS1 from strain C58 coding for agrocinopine A production), Agrobacterium ACS2 (function unknown), and I. batatas ACS (IbACS), whereas group 2 contains ACS closely related to ACS from A. tumefaciens Bo542 for agrocinopine C production. Alignment of ACS proteins from Agrobacterium and I. batatas indicated that there are some conserved amino acids for ACSs in group 1 and group 2, respectively (Supplementary Fig. S2). These results suggested that IbACS1 is more closely related to ACS for agrocinopine A production.

\section{Heterologous expression of I. batatas ACS1 gene in Nicotiana tabacum.}

To identify the substance produced by IbACS1 in the plant, IbACS1 was heterologously expressed in N. tabacum under the control of the cauliflower mosaic virus $35 \mathrm{~S}$ promoter. From 20 kanamycin-resistant $N$. tabacum transformants containing the expression vector for $I b A C S 1$, two lines with stable expression of IbACS1 (ACS5 and ACS18) were selected after analysis by real-time reverse transcription (RT)-PCR (Fig. 2). Expression of IbACS1 in leaves of these ACS transformants was almost equivalent to that of the N. tabacum internal standard L25 gene (Fig. 2B). These selected transformants expressing IbACSI as well as control plants harboring an empty vector (EV) were used for further analysis. The growth and morphology of $N$. tabacum were not significantly affected by the overexpression of IbACSI (Fig. 2A).
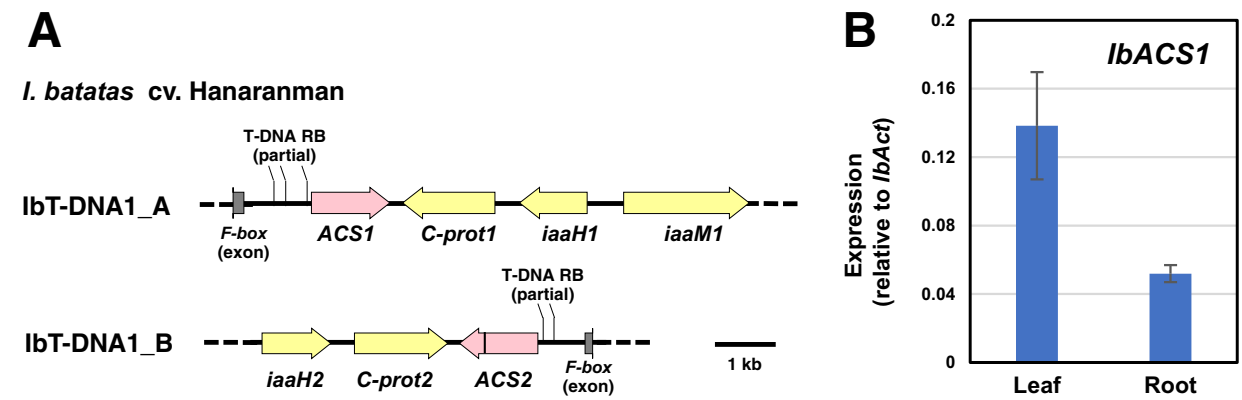

Fig. 1. T-DNAs in the genome of Ipomoea batatas. A, Physical map of IbT-DNA1_A and IbT-DNA1_B sequences in the genome of $I$. batatas cv. Hanaranman. Predicted coding sequences are shown as arrows. Vertical line in IbACS2 indicates the internal stop codon. Partial sequences for T-DNA right border (RB) and adjacent exons for the $F$ box gene (gray box) conserved among plant species are indicated. B, The expression of IbACS1 gene in leaf and root tissues of $I$. batatas cv. Hanaranman. Data are mean \pm standard error $(n=3)$. 
To detect the substance produced by IbACS1 in transgenic $N$. tabacum, crude extracts were prepared from control or IbACS1expressing tobacco leaves. Crown gall was induced on tomato stems by inoculating a pathogenic strain of A. tumefaciens (strain MAFF301001) to extract agrocinopine A naturally produced by Agrobacterium infection. Extracts from tobacco leaves or tumors on tomato were separated by high-voltage paper electrophoresis (HVPE) at $\mathrm{pH}$ 1.7. Silver nitrate staining detected a spot (mobility relative to Orange $\mathrm{G}, \mathrm{Rm}_{\mathrm{OG}}=0.00$ ) common in all samples, which is considered to be fructose and other neutral sugars. A second spot, in each case migrating a similar distance $\left(\mathrm{Rm}_{\mathrm{OG}}=0.39\right)$, was detected in the extracts from IbACS1expressing tobacco leaves and from tomato tumors, whereas the corresponding substance was not detected in the extract from the control (EV) tobacco tissue (Fig. 2C). Therefore, the substance with electrophoretic mobility $\mathrm{Rm}_{\mathrm{OG}} 0.39$ detected in IbACS1-expressing tobacco was considered to represent a product of IbACS that has molecular characteristics similar to the agrocinopine produced in tomato by Agrobacterium infection.

Sweet potato tissues produce an agrocinopine-like substance.

The extracts from leaf, stem, root, and tuber of sweet potato were concentrated and separated by HVPE. Silver nitrate staining detected spots migrating a similar distance $\left(\mathrm{Rm}_{\mathrm{OG}}=0.39\right)$ to agrocinopine $\mathrm{A}$, suggesting that an agrocinopine-like substance is produced in different tissues of sweet potato (Fig. 2D).

\section{Identification of agrocinopine $A$ as the substance produced in IbACSI-expressing $N$. tabacum.}

After separation by HVPE, the spot for the product of IbACS1-expressing tobacco ACS5 was excised and the eluted substance was used for analysis by matrix-assisted laser desorption-ionization quadrupole ion trap mass spectrometry (MALDI-QIT-TOF-MS). Figure 3A shows MALDI-QIT-TOF MS ion spectra of IbACS1-expressing and control EV tobacco in the negative ion mode. The analysis detected a deprotonated molecular ion $\left([\mathrm{M}-\mathrm{H}]^{-}, m / z, 553\right)$ specific to the mass spectrum for the IbACS1-expressing tobacco sample. Since further structural analysis was considered necessary, the substance produced in IbACS-expressing tobacco was extracted and purified by a series of ion-exchange and gel-filtration chromatography steps by reference to previous reports (Messens et al. 1986; Ryder et al. 1984). Its molecular formula was determined by high resolution negative electrospray ionization (ESI) MS to be $\mathrm{C}_{17} \mathrm{H}_{31} \mathrm{O}_{18} \mathrm{P}$ (observed $\mathrm{m} / \mathrm{z}$ of 553.1177 , calculated for
A

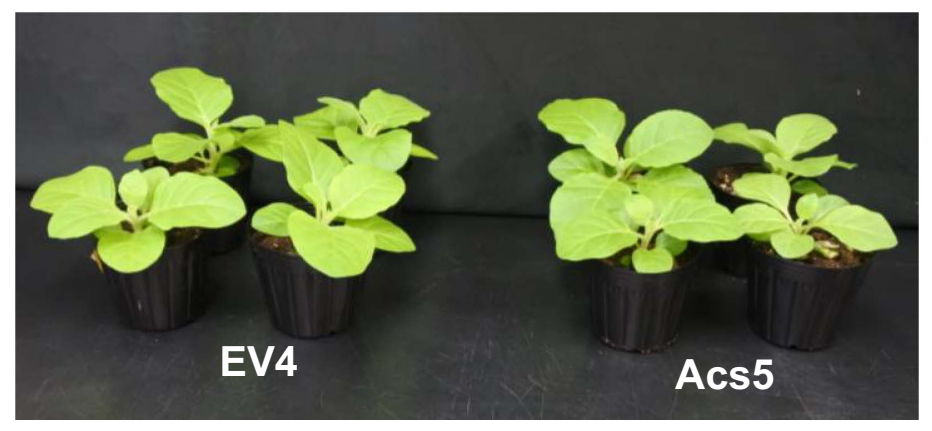

B

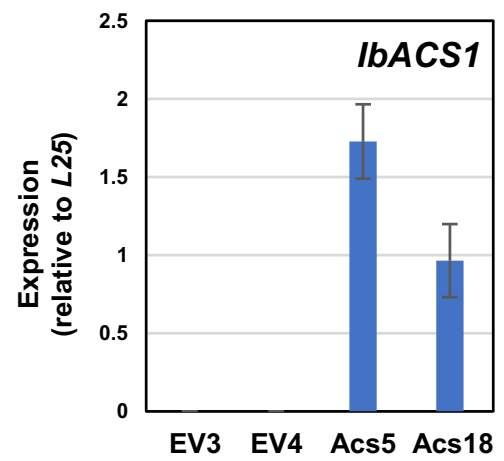

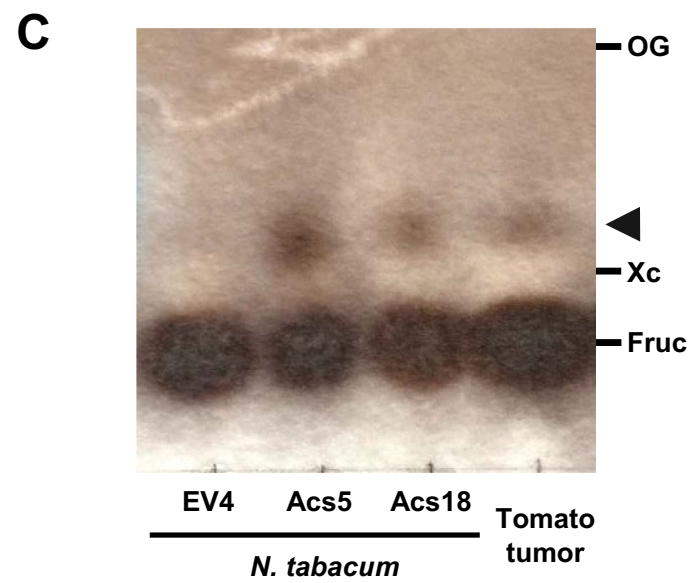

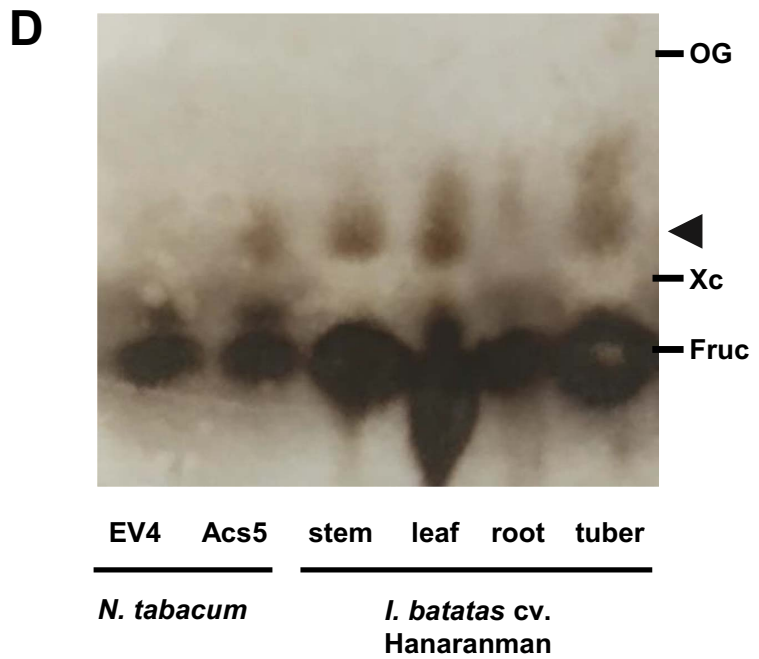

Fig. 2. Heterologous expression of the Ipomoea batatas ACS1 gene in Nicotiana tabacum. A, Growth of transgenic tobacco containing empty vector pEl2W (EV4) or pEl2W-IbACS for IbACS1 expression under the control of 35S promoter (Acs5). Plants were grown for approximately 5 weeks. B, The expression of IbACS1 in leaves of control (EV) or IbACS1-expressing tobacco (Acs). Expression level relative to internal reference gene L25 (Schmidt and Delaney 2010) is shown. C, Extracts from leaves of tobacco transformants or tomato tumors induced by Agrobacterium infection were subjected to high-voltage paper electrophoresis (HVPE) in formic acid-acetic acid buffer. Arrowhead indicates the substance detected in IbACS1-expressing tobacco and tomato tumor. Representative data of at least 10 separate experiments. D, Extracts from leaves of tobacco transformants or sweet potato tissues were subjected to HVPE. An arrowhead indicates the substance detected in IbACS1-expressing tobacco and sweet potato. Representative data of at least five separate experiments. $\mathrm{OG}=$ orange $\mathrm{G}, \mathrm{Xc}=$ Xylene cyanol, and Fruc $=$ fructose. 
$\left.\mathrm{C}_{17} \mathrm{H}_{30} \mathrm{O}_{18} \mathrm{P}[\mathrm{M}-\mathrm{H}]^{-}=553.1175\right)$, the value of which was comparable to the deprotonated molecular weight of agrocinopine $\mathrm{A}$ (Ryder et al. 1984). Its MS/MS analysis showed distinct fragment peaks at $\mathrm{m} / \mathrm{z}=421,373,229$, and 221 (Fig. 3B). Among these fragments, peaks at $m / z=421,229$, and 221 possibly corresponded to (4- $O$-phospho- $\beta$-D-fructofuranosyl)D-glucopyranoside, L-arabinose-2-phosphate, and dehydrated L-arabinose-2-phosphate, respectively (Fig. 3B). Another distinct fragment at $m / z=373\left(\mathrm{C}_{11} \mathrm{H}_{18} \mathrm{O}_{12} \mathrm{P}\right)$ could be formed by cleavage of D-glucosyl and water moieties at the position shown in Figure 3B. Finally, the ${ }^{1} \mathrm{H}$ and ${ }^{13} \mathrm{C}$ nuclear magnetic resonance (NMR) assignments are shown in Supplementary Table S1. All chemical shifts and their connectivity showed good agreement with the data reported for agrocinopine A (Messens et al. 1986; Ryder et al. 1984) (Supplementary Table S1; Supplementary Fig. S3). Thus, the substance produced by IbACS in tobacco is agrocinopine A (Fig. 3). The stereoisomeric ratio at $\mathrm{C}-1$ of the $\mathrm{L}$-arabinose moiety was estimated to be $\alpha: \beta=1: 2$ based on the peak intensity in ${ }^{1} \mathrm{H}$ NMR.

\section{Biological activity of agrocinopine A produced in tobacco by IbACS.}

The concentrated samples from HVPE spots $\left(\mathrm{pH} 1.7, \mathrm{Rm}_{\mathrm{OG}}=\right.$ 0.39) of leaf extract from $N$. tabacum expressing IbACS1, tomato crown galls, and the corresponding area of EV tobacco plants were subjected to a bioassay using agrocin 84 and the indicator
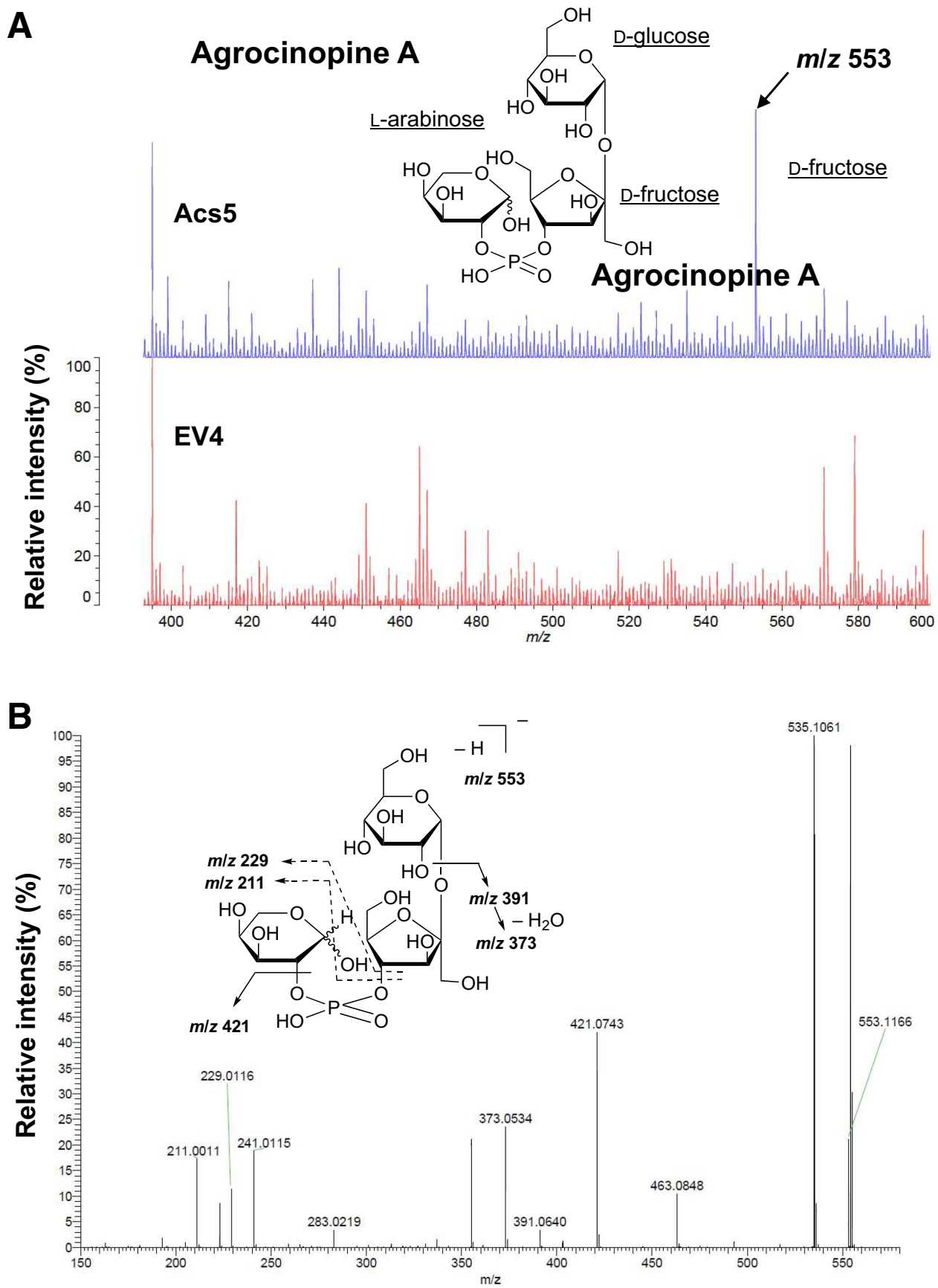

Fig. 3. Identification of agrocinopine A produced by Ipomoea batatas agrocinopine synthase (ACS) in transgenic tobacco. A, Negative-ion mass spectrum of the IbACS1 product detected in the IbACS1-expressing tobacco (Acs5) leaves, using matrix-assisted laser desorption-ionization quadrupole ion trap mass spectrometry (MS). B, Electrospray ionization collision-induced dissociation MS/MS spectrum of a precursor ion at $\mathrm{m} / z$. 553, using an LTQOrbitrap mass spectrometer. 
strain K293, which harbors pTiT37 (Guyon et al. 1980). In this assay, the presence of agrocinopine A further induces the uptake of agrocin 84 by K293, causing an extension of the zone of inhibition of the growth of this strain and a marked sharpening of the edge of the zone (Ellis and Murphy 1981). The substance from IbACS1-expressing tobacco, as well as agrocinopine from tomato tumor, clearly extended and sharpened the edge of the inhibition zone of the growth of K293 compared with the extract from control N. tabacum (Fig. 4). These results indicated that the substance produced by IbACS in the plant has the activity expected of agrocinopine A. The putative agrocinopine samples did not inhibit the growth of the indicator strain in the absence of agrocin production (Supplementary Fig. S4), indicating that the observed extension of the inhibition zone was the result of an interaction. The substance migrating at $\mathrm{Rm}_{\mathrm{OG}}=0.39$ did not induce agrocin 84 sensitivity in A. radiobacter K923, which carries pTiBo542 coding for agrocinopine $\mathrm{C}$ production, uptake, and catabolism, i.e., the compound did not have the activity expected of agrocinopine $\mathrm{C}$ (data not shown).

\section{Effect of IbACS1 expression on the bacterial community} structure in the rhizosphere of transgenic $N$. tabacum.

The effect of agrocinopine A production on the rhizosphere microbial community of tobacco was investigated. First, control and IbACS1-expressing tobacco were grown on MS agar medium for 5 weeks, were transferred to sterilized soil for 2 weeks, and were then transplanted and grown in soil supplemented with approximately $10 \%$ (vol/vol) soil from agricultural fields, and were grown for another 10 days. Growth of the control and the IbACS1-expressing tobacco showed no significant difference (Fig. 5A). Roots were ground and microorganisms in the extract were isolated on yeast mannitol (YM) agar (Fig. 5B). The population of total aerobic bacteria on the roots was significantly increased in IbACSI-expressing tobacco compared with that for the control tobacco (Fig. 5C). Based on 16S ribosomal RNA (rRNA) sequence analysis, the genera of colonies isolated from control and IbACS1-expressing tobacco were estimated. The sequencing result showed that $53 \%$ of randomly selected colonies from IbACS1-expressing tobacco plants $(n=15)$ were assigned to Leifsonia sp., and colonies of this genus were not isolated from the control tobacco roots $(n=10)$.

Root samples of control and IbACS1-expressing tobacco were subjected to $16 \mathrm{~S}$ rRNA amplicon sequencing to further characterize the effect of agrocinopine A production on bacterial composition in the root tissue and rhizoplane of transgenic tobacco.
The V3-V4 region of the 16S rRNA gene was amplified by PCR using the DNA extracted from $N$. tabacum roots (four biological replicates each). The sequence reads from each sample were analyzed to detect the differences in the bacterial community between control and IbACS1-expressing tobacco plants. Among the OTUs (operational taxonomic units) detected (Supplementary Table S2), the relative abundances of the actinobacterial genera Leifsonia were significantly $(P<0.002)$ enriched in the IbACS1-expressing tobacco plants grown in soils amended with live soil from agricultural fields, whereas reads corresponding to three OTUs (family Microbacteriaceae and genus Humibacter) were reduced in the IbACS1-expressing tobacco (Fig. 5C), suggesting that production of agrocinopine A influenced the rhizosphere microbial community of tobacco.

\section{Leifsonia sp. strain LS1 enriched in the rhizosphere of IbACS1-expressing tobacco possesses an operon for sugar phosphate transport and metabolism.}

The root samples of control and IbACSI-expressing tobacco were also subjected to metaRNA-seq analysis, to compare the patterns of gene expression in the two microbial communities. Ribosomal depleted RNA was prepared from root tissues of control and IbACS1-expressing tobacco (three biological replicates each), and the sequencing of the libraries generated 19 to 31 million quality-filtered reads for the control and IbACSIexpressing samples. The reads after quality trimming were subjected to de novo assembly, resulting in 78,144 unique contigs. Based on a blast search of contigs, 2.1 and $0.2 \%$ of the contigs were annotated as bacterial and fungal sequences, respectively. In total, 26 genes were identified as being expressed differently between microbial communities associated with control and IbACS1-expressing plants $(P<0.01$, false discovery rate $<0.1)$. Consistent with 16S rRNA sequencing (Fig. 5C), 10 of 17 $(59 \%)$ of the transcripts abundant in the IbACS1-expressing roots were assigned to Leifsonia sp. (Supplementary Table S3). Among transcripts abundant in IbACS1-expressing tobacco roots, contig S2087290 encodes a sugar ABC transporter permease with significant homology to that of Streptomyces shenzhenensis 193, an endophytic bacterium isolated from guarana. The sequence of contig S2087290 was amplified by PCR from RNA samples of IbACS1-expressing tobacco and the genomic DNA of Leifsonia sp. isolated from the rhizosphere of IbACS1-expressing tobacco (Supplementary Fig. S5). To further analyze the Leifsonia sp. that multiplied in the rhizosphere of IbACS1-expressing tobacco, an isolate named LS1 was subjected

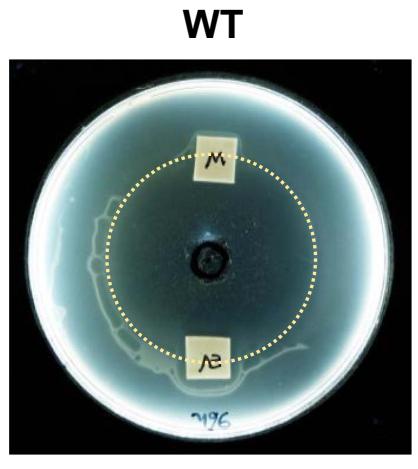

EV4
Tomato tumor

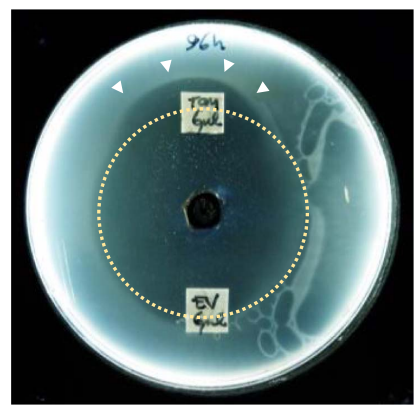

EV4

Fig. 4. Agrocinopine activity of the substance produced by Ipomoea batatas ACS1 in tobacco. Extracts from leaves of wild type (WT), control tobacco (EV4), IbACS1-expressing tobacco (Acs5), or tomato stem inoculated with Agrobacterium tumefaciens (tomato tumor), were subjected to high-voltage paper electrophoresis. Substances extracted were spotted on filter paper and were placed on the plate containing agrocin 84 produced by strain K1026. The plate was then sterilized with chloroform vapor, was overlaid with indicator strain $\mathrm{K} 293$ in soft agar, and was incubated at $27^{\circ} \mathrm{C}$ for 96 h. Arrowheads indicate the increased inhibition zone. 
to genome sequencing. The LS1 genome shares identities with other strains from the Leifsonia genus with ANI (average nucleotide identity) of 77 to $87 \%$ (Supplementary Table S4), which is a value below the threshold of $95 \%$ identity that would serve as a boundary for species circumscription (Barco et al. 2020; Konstantinidis and Tiedje 2005), thus isolate LS1 represents a new genomospecies belonging to the genus Leifsonia. The sequence of contig S2087290 was found in the LS1 genome as a part of a putative operon composed of seven predicted open reading frames, including three genes encoding components of a sugar ABC transporter, phosphatase, phosphodiesterase, and a LacI/ GalR family transcription factor (Fig. 6). A homologous operon was also found in a few $A$. tumefaciens strains. The putative operon in A. tumefaciens IL15 has predicted genes for sugar phosphate metabolism composed of three components of a sugar transporter, phosphatase, phosphodiesterase, and a DeoR/GlpR family transcription factor, which is analogous (but not significantly homologous) to the previously identified Acc operon for agrocinopine catabolism (Hayman and Farrand 1988; Hayman et al. 1993; Kim and Farrand 1997). These results suggest that Leifsonia sp. strain LS1 contains an operon for sugar phosphate uptake and metabolism. The corresponding operon was not identified in 28 sequenced Leifsonia species (in the database of the European Bioinformatics Institute, EMBL-EBI).

\section{Leifsonia sp. strain LS1 catabolizes agrocinopine A produced by IbACS1-expressing tobacco.}

Next, we investigated whether Leifsonia sp. strain LS1 can utilize agrocinopine A. Leifsonia sp. strain LS1, A. tumefaciens MAFF301001, and Escherichia coli S17-1 were incubated with an extract of $I b A C S 1$-expressing tobacco at $28^{\circ} \mathrm{C}$ for $24 \mathrm{~h}$. The extracts were then subjected to HVPE analysis to detect remaining agrocinopine A. Agrocinopine A $\left(\mathrm{Rm}_{\mathrm{OG}}=0.39\right)$ was detected in the sample incubated with $E$. coli, while incubation with A. tumefaciens and Leifsonia sp. strain LS1 caused a significant reduction of agrocinopine $\mathrm{A}$ in the extract. In contrast, the spots for neutral sugars including fructose $\left(\mathrm{Rm}_{\mathrm{OG}}=0.00\right)$ were reduced after the incubation with all bacterial species (Fig. 7A). Moreover, we tested the effect of agrocinopine A on the growth of Leifsonia sp. strain LS1. While the multiplication of LS1 was promoted by agrocinopine A treatment, the growth of $E$. coli was not affected (Fig. 7B). When Leifsonia sp. strain LS1 was inoculated into the rhizosphere of the transgenic tobacco lines, the biomass of LS1 was significantly higher in IbACSIexpressing tobacco than in the control plant (Supplementary Fig. S6). These results indicated that Leifsonia sp. strain LS1 catabolizes and assimilates agrocinopine A produced in tobacco by IbACS1.

\section{DISCUSSION}

HGT is particularly widespread in prokaryotic organisms and is considered an important driving force in their evolution by increasing genetic variation (Ochman et al. 2000). Although its frequency is significantly low compared with that of prokaryotes, HGT can occur between prokaryote and eukaryote or between eukaryotes. Generally, HGTs between distant species are considered as rather passive events, but Agrobacterium sp. have dedicated mechanisms for active HGT (Lacroix and Citovsky 2019). The pathogens use HGT for their benefit, including the proliferation of host cells and the production of substances that are (considered to be) specifically assimilated by the pathogen.
A

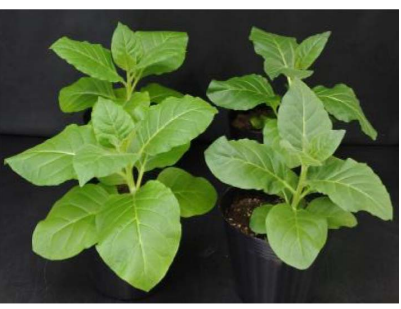

EV4

Acs5
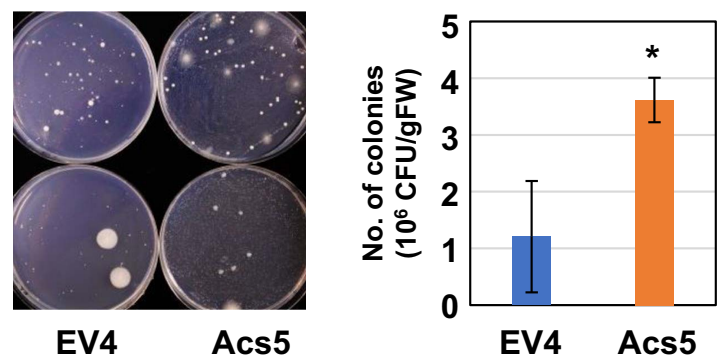

C

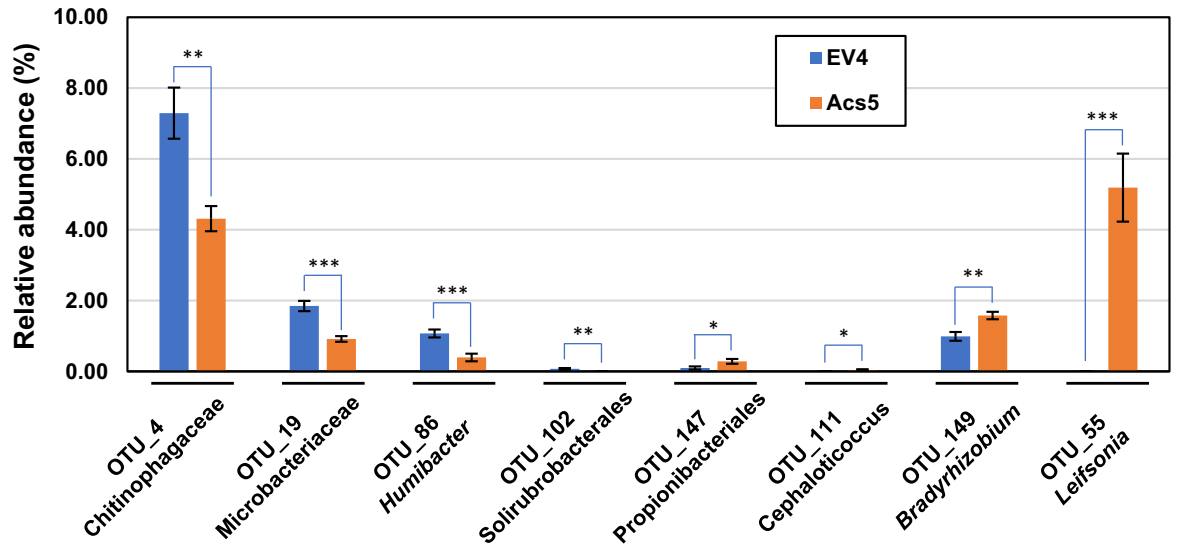

Fig. 5. Effect of agrocinopine A production on the rhizosphere bacterial community of tobacco. A, Growth of transgenic tobacco containing the empty vector (EV4) or pEl2W- IbACS (Acs5). Plants were grown in sterilized soil supplemented approximately 10\% (vol/vol) with soil from an agricultural field. B, Extracts from root tissue of tobacco transformants were inoculated on yeast mannitol media and were cultured for 3 days at $28^{\circ} \mathrm{C}$ (left). The number of colonies were counted 3 days after inoculation $(n=3)$. (right). $\mathbf{C}$, Relative abundances of rhizosphere microbial taxa $($ OUT $=$ operational taxonomic unit) showed significant differences between EV4 and Acs5 plants. Data are mean \pm standard error $(n=4)$. One asterisk $(*)$ indicates $P<0.1$, two $\left(^{* *}\right) P<0.05$, and three $(* * *) P<0.01$. 


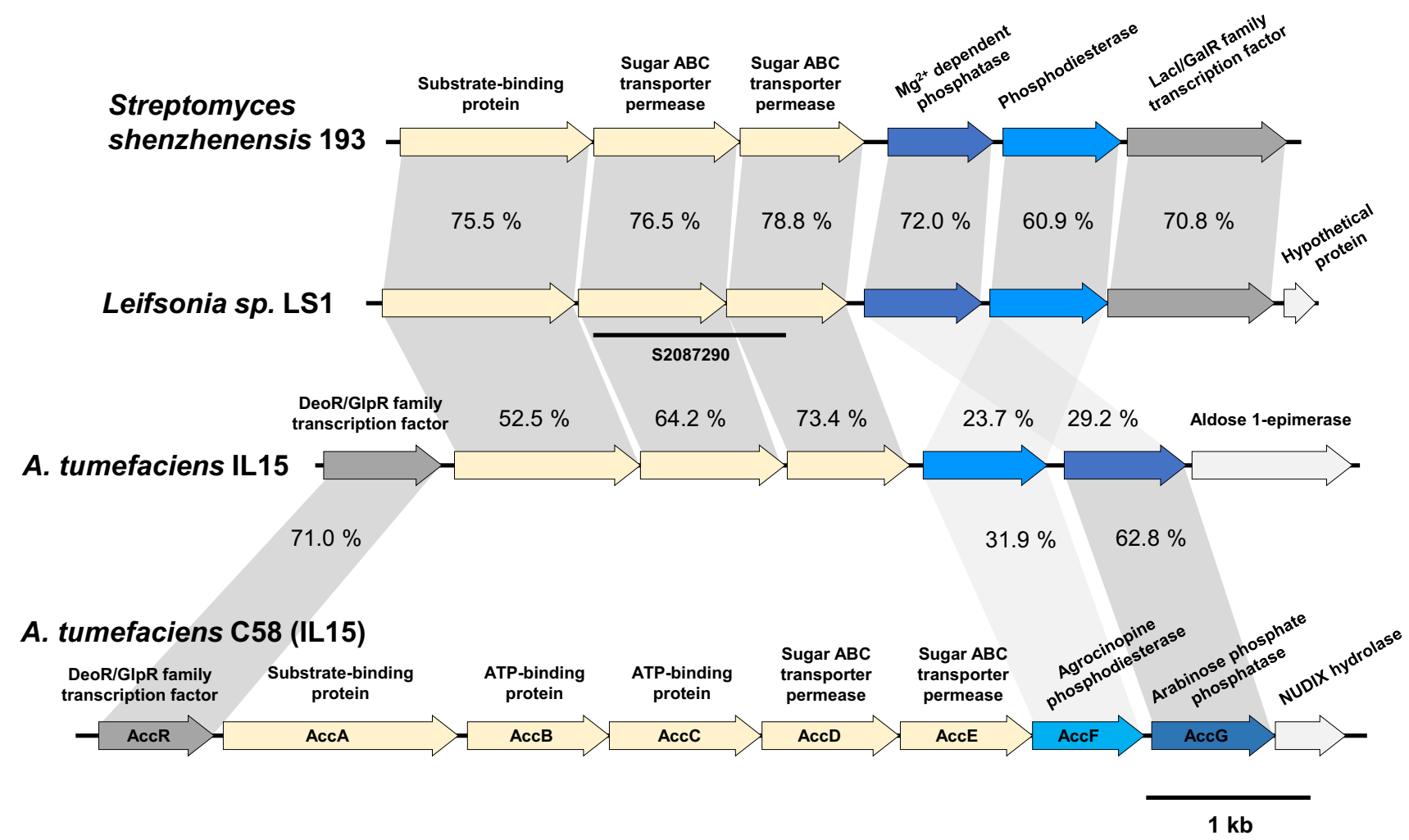

Fig. 6. An operon of Leifsonia sp. strain LS1 enriched in the rhizosphere of IbACS1-expressing tobacco and homologous operons from Streptomyces shenzhenensis 193 and Agrobacterium tumefaciens IL15. The Agrobacterium Acc operon for agrocinopine assimilation in strain C58 is shown. Note that an almost identical Acc operon is also found in strain IL15. Amino acid identities (\%) between homologous proteins are shown in gray boxes.

A

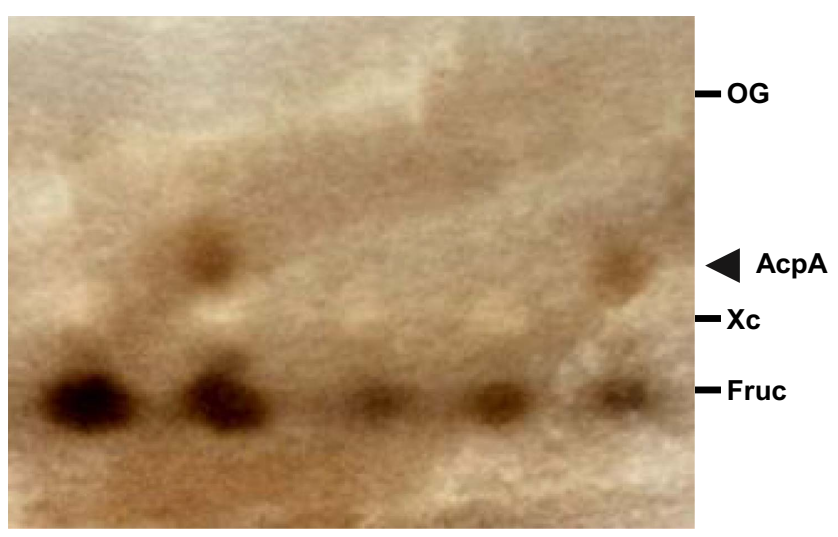

EV4
Acs5

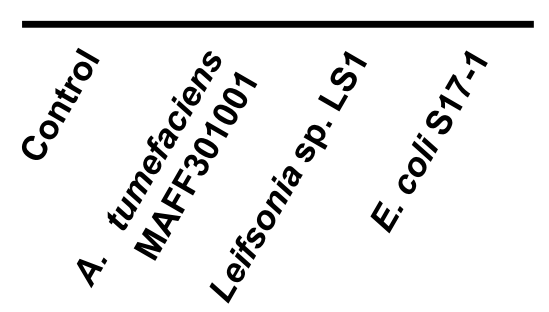

B

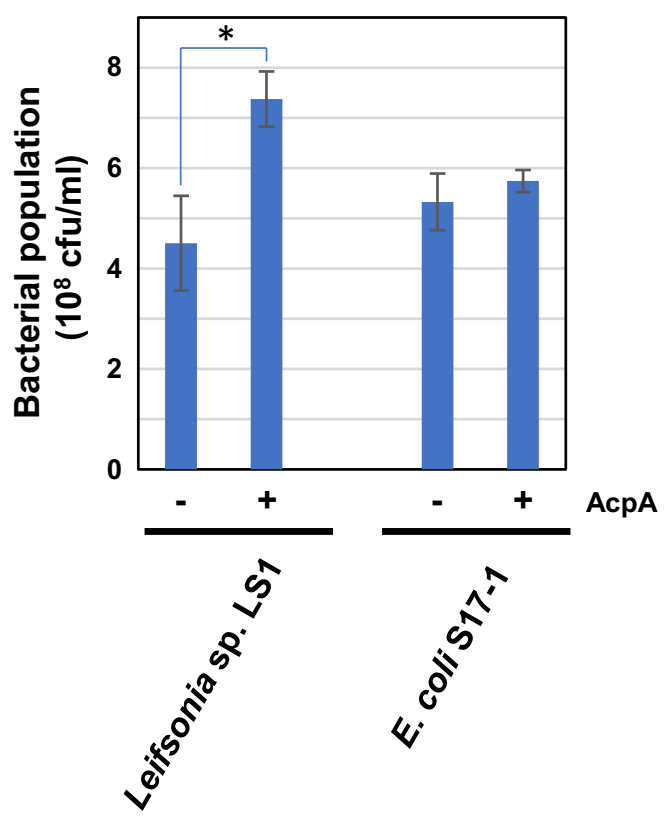

Fig. 7. A, Extracts from leaves of $I b A C S 1$-expressing tobacco (Acs5) were incubated with the bacteria indicated at $28^{\circ} \mathrm{C}$ for $24 \mathrm{~h}$. Extracts from tobacco with empty vector (EV4), IbACS1-expressing tobacco incubated with or without (control) bacterial strains were subjected to high-voltage paper electrophoresis (HVPE) in formic acid-acetic acid buffer. Arrowhead indicates agrocinopine A (AcpA). Representative data of at least three separate experiments. OG $=$ orange $\mathrm{G}, \mathrm{Xc}=$ Xylene cyanol, and Fruc $=$ fructose. B, Bacterial strains were incubated in leaf extracts of tobacco supplemented with or without $250 \mathrm{ng}$ of AcpA per microliter at $28^{\circ} \mathrm{C}$, and bacterial population was determined after $24 \mathrm{~h}$. Data are means \pm standard error $(n=4)$. An asterisk indicates data are significantly different, as assessed by two-tailed Student's $t$ tests, $P<0.05$. 
Agrobacterium sp. have been commonly utilized for the artificial transformation of crop species for agricultural purposes, including production of species with enriched nutrient content (e.g., Golden rice [Ye et al. 2000]), herbicide resistance (Duke 2015), and pest resistances (Anderson et al. 2019). While the use of artificial genetic modification of crops has been controversial, recent analyses of rapidly increasing genomic information revealed that some crops are naturally transgenic and these contain and express Agrobacterium genes (Matveeva and Otten 2019).

In this study, we have shown that the IbACS1 gene derived from (ancestral) Agrobacterium encodes a functional enzyme. Expression of IbACSI was detected in different tissues of sweet potato and the product of IbACSI in transgenic tobacco was identified as agrocinopine A. The pathways for biosynthesis of agrocinopines in crown gall tumors have not been elucidated. However, it is clear from this work that a single ACS gene is sufficient for a plant cell to be able to synthesize agrocinopine A from existing metabolites. The substrates for ACS, presumably sugar phosphates, and the possible energy/ ATP requirement for the synthesis reaction remain to be established.

An agrocinopine A-like substance was also detected in tissues of sweet potato, suggesting that IbACS1 could be enzymatically active in sweet potato. In Nicotiana glauca, homologous genes for mikimopine (an opine) production, misL and misR, were identified in cT-DNA and their expression was detected (Suzuki et al. 2002). Kovacova et al. (2014) indicated that mis genes in $N$. glauca evolved under significant selective pressures. This also suggested that mikimopine could have a role in ancestral and current $N$. glauca, in contrast to the mis gene in the genus Linaria sp., which degenerated shortly after the HGT. Given that the IbACS gene is retained in many cultivated hexaploid I. batatas cultivars examined, it was expected that the IbACS gene could be conserved in cultivated sweet potato under selective pressure associated with gene expression and one or more functions.

Previous studies indicated that the soil microbiota is affected by overproduction of mannityl opines in transgenic plants (Guyon et al. 1993; Oger et al. 1997; Savka and Farrand 1997). In this study, the production of agrocinopine $\mathrm{A}$ in $N$. tabacum containing IbACS altered the microbial community within and surrounding the root tissues (Fig. 5), probably by attracting or enriching particular microbial strains. 16S rRNA amplicon sequencing identified new species of Leifsonia (actinobacteria) that were enriched in IbACS1-expressing tobacco roots. The actinobacterial isolate Leifsonia sp. strain LS1 was able to catabolize agrocinopine A, suggesting that LS1 had an advantage and so was able to preferentially multiply in the rhizosphere containing agrocinopine A. Agrobacterium spp. can engineer an ecological niche in the tumor by the diversion of plant metabolism toward production of one or more particular opines, which are beneficial for Agrobacterium spp. with the corresponding genes or operons for their assimilation (Lang et al. 2014). Catabolism of agrocinopine A by Leifsonia sp. strain LS1 indicated that there are environmental microbes apart from Agrobacterium spp. that can utilize agrocinopine A. Previous reports indicated that some soil and rhizosphere microbes are able to import and catabolize or assimilate other opines, such as the secondary amine derivatives (Beauchamp et al. 1990; Moore et al. 1997; Tremblay et al. 1987). MetaRNA-seq analysis identified a gene encoding a sugar transporter of strain LS1 as one of the genes enriched in the rhizosphere of IbACS1-expressing tobacco. The enriched operon of LS1 included genes encoding components of a sugar $\mathrm{ABC}$ transporter, phosphatase, and phosphodiesterase, suggesting a role in sugar phosphate uptake and metabolism. The Acc operon for agrocinopine assimilation has been identified for Agrobacterium spp., including genes for sugar transport (AccA to AccE), arabinose phosphate phosphatase (AccG), and agrocinopine phosphodiesterase (AccF) (Hayman and Farrand 1988; Hayman et al. 1993; Kim and Farrand 1997). Although similar sets of proteins and enzymes are encoded in the LS1 operon and the Agrobacterium sp. strain C58 Acc operon, their homologies are relatively low; thus, further analysis is required to determine the role of the components of the LS1 operon in sugar phosphate metabolism. A homologous operon can be found in some actinobacteria (e.g., Streptomyces and Kribbella species) and proteobacteria (e.g., Agrobacterium/Rhizobium species), but the operon was not conserved in particular genera and species of bacteria, indicating that this operon could be transferred to taxonomically distant bacterial strains by HGT. A recent analysis by Matveeva and Otten (2019) showed that natural transformation and inheritance of cT-DNA genes occurs in an unexpectedly wide range of plants. Thus, it is likely that some natural plant species produce opines in nature, which could attract and be consumed by symbiotic or environmental microbes.

Although the composition of the rhizosphere microbial community of tobacco was affected by artificially induced production of agrocinopine $\mathrm{A}$, there was no detectable effect of agrocinopine A production on the growth of transgenic tobacco under our experimental conditions. Rhizosphere microbes enriched due to agrocinopine A production may be beneficial particularly for sweet potato. We are producing IbACS1 knockouts in sweet potato, and the characterization of $I b A C S I$ knockout sweet potato may reveal the role of the IbACS1 gene derived from genus Agrobacterium for the evolution of Ipomea species. It is also possible that the expression of $I b A C S$, including a possible contribution to taste or other characteristics of the crop, has contributed to the original and continued selection of sweet potato by Homo sapiens.

\section{MATERIALS AND METHODS}

Biological materials and growth conditions.

Sweet potato (I. batatas) cultivars Hanaranman and White Star were obtained from Kyushu Okinawa Agricultural Research Center, the National Agriculture and Food Research Organization (NARO, Japan) and were grown on Murashige-Skoog agar at $25^{\circ} \mathrm{C}$ and 16-h-light and 8-h-dark cycle. N. tabacum cv. Samsun $\mathrm{NN}$ was grown in an environmentally controlled growth room at $25^{\circ} \mathrm{C}$ under $16 \mathrm{~h}$ of light and $8 \mathrm{~h}$ of dark per day. A. tumefaciens (syn. Rhizobium radiobacter) MAFF301001 (Suzuki et al. 2000), originally isolated from the Sakura tree, was obtained from the collection of the National Institute of Agrobiological Sciences (Japan) and was grown on LB medium at $28^{\circ} \mathrm{C}$.

A. rhizogenes K1026, derived from strain K84 (Jones and Kerr 1989), was obtained from A. Kerr, University of Adelaide. A. radiobacter $\mathrm{K} 293$ (a nopaline/agrocinopine A strain) is a constitutive nopaline catabolic derivative of A. radiobacter T37, originally obtained from G. Morel. A. radiobacter K923 was derived from the nonpathogenic (cured) A. radiobacter $\mathrm{C} 58 \mathrm{C} 1$ by insertion of pTiBo542 (agropine/agrocinopine C type) by J. Ellis.

\section{Isolation of genomic DNA from $I$. batatas and amplification and sequencing of the IbT-DNA locus.}

Genomic DNA of I. batatas cv. Hanaranman was extracted using a DNeasy Plant mini kit (Qiagen, Düsseldorf, Germany), following the manufacturer instructions. IbT-DNA1_A and IbTDNA1_B were amplified using PrimeSTAR Max DNA Polymerase (Takara Bio, Kusatsu, Japan) and were sequenced using primers listed in Supplementary Table S5. Primers were designed 
based on the sequence data for the IbT-DNA1 bacterial artificial chromosome clone for I. batatas cv. Xu781 (accession number KM113766 [Kyndt et al. 2015]). The sequence of IbT-DNA1_A was extended by combining it with the iaaM sequence obtained by meta-transcriptome analysis.

\section{Preparation of RNA and quantitative RT-PCR (qPCR) analysis.}

Total RNA was isolated from frozen tobacco leaf tissue using the NucleoSpin RNA Plant kit (Takara Bio). cDNA was synthesized from total RNA with an oligo(dT) primer and random primers, using PrimeScript RT reagent Kit (Takara Bio). Genespecific amplifications of cDNA were performed in a LightCycler Quick System 350S (Roche, Basel, Switzerland), using SYBR Premix Ex Taq (Takara Bio). The thermal cycle conditions used were: one cycle at $95^{\circ} \mathrm{C}$ for $30 \mathrm{~s}$, then, 40 cycles at $95^{\circ} \mathrm{C}$ for $10 \mathrm{~s}, 60^{\circ} \mathrm{C}$ for $5 \mathrm{~s}$, and $72^{\circ} \mathrm{C}$ for $30 \mathrm{~s}$, using single fluorescence acquisition. The melting curve was generated by holding the sample at $65^{\circ} \mathrm{C}$ for $30 \mathrm{~s}$, followed by ramping up to $95^{\circ} \mathrm{C}$ at a rate of $0.2^{\circ} \mathrm{Cper}$ second, using continuous fluorescence acquisition. Each sample was analyzed in duplicate for each primer combination. The melting curves were used to determine whether there was specific amplification of each product, and this was confirmed by electrophoresis of the reaction products through a $2 \%$ agarose gel. The relative expression level of IbACS in I. batatas and N. tabacum was normalized to that of the I. batatas actin gene and the N. tabacum L25 gene, respectively (Schmidt and Delaney 2010).

\section{Preparation of the IbACS1 construct and plant transformation.}

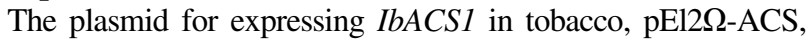
was constructed using the In-Fusion HD cloning kit (Takara Bio). IbACS from the cultivar White Star was PCR-amplified using PrimeSTAR Max DNA polymerase (Takara Bio) and was cloned into BamHI-digested pEl2 $\Omega$ vector (Ohtsubo et al. 1999). $N$. tabacum was transformed as described previously (Ohshima et al. 1999), using A. tumefaciens EHA105 containing $\mathrm{pEl} 2 \Omega$ or $\mathrm{pE} 2 \Omega-\mathrm{ACS}$.

\section{HVPE of plant extracts.}

Tomato plants grown for 4 weeks were inoculated with $A$. tumefaciens MAFF301001 and were further grown for approximately 4 weeks to allow tumor development. Tomato tumors were cut into 5-mm pieces and were soaked in $70 \%$ ethanol overnight, as described by Ryder et al. (1984). Tissue fragments were removed by centrifugation for $5 \mathrm{~min}$ at $5,000 \times g$, and the supernatant solutions were concentrated using a sample concentrator with the heater set at $50^{\circ} \mathrm{C}$. For tobacco or sweet potato samples, leaf tissues (approximately $500 \mathrm{mg}$ ) were frozen and ground in 1.5-ml microcentrifuge tubes with a polypropylene pestle. The supernatant solutions were collected by centrifugation for $5 \mathrm{~min}$ at $5,000 \times g$. Samples from tomato tumor $(5 \mu \mathrm{l})$, tobacco leaf $(5$ $\mu \mathrm{l})$, and various tissues of sweet potato $(10 \mu \mathrm{l})$ were then separated by HVPE in $0.76 \mathrm{M}$ formic acid and $1.03 \mathrm{M}$ acetic acid buffer, $\mathrm{pH}$ 1.7, on Whatman 3MM paper (Little Chalfont, Buckinghamshire, U.K.) at $500 \mathrm{~V}$ for $20 \mathrm{~min}$, using a vertical electrophoresis apparatus (Nipron, Nagoya, Japan) and separated spots were visualized by staining with alkaline silver nitrate, which detects sugars (Trevelyan et al. 1950). Orange G, xylene cyanole, and fructose $\left(\mathrm{Rm}_{\mathrm{OG}}=0.00\right)$ were used as reference markers.

\section{MALDI-QIT-TOF MS.}

MS analysis was performed with a MALDI-QIT-TOF mass spectrometer (AXIMA-QIT, Shimadzu, Kyoto, Japan). Tobacco leaf extracts $(200 \mu \mathrm{l})$ were separated by HVPE. The regions containing an agrocinopine-like substance or the corresponding area of a control sample were cut out and immersed in $4 \mathrm{ml}$ of water. The extract was centrifuged for $10 \mathrm{~min}$ at $13,000 \times g$ at $20^{\circ} \mathrm{C}$. A $0.3-\mu \mathrm{l}$ aliquot of the supernatant solution was mixed with an equal amount of DHB matrix $(50 \mathrm{mg} / \mathrm{ml}$ in $50 \%$ acetonitrile, $0.1 \%$ triflouroacetic acid solution) on a MALDI target plate and was air-dried. Analyses were performed in a negative ion mode. The mass range was set to 50 to $700 \mathrm{~m} / \mathrm{z}$.

\section{Orbitrap MS and MS/MS analysis.}

The IbACS1 product extracted from tobacco leaves (discussed above) was diluted 10 times with acetonitrile and water (50:50) and was injected into an Accela LC system coupled to a Hybrid Ion Trap-Orbitrap Mass Spectrometer LTQ Orbitrap XL (Thermo Fisher Scientific, Bremen, Germany). ESI-MS and MS/MS spectra were obtained by flow injection analysis using a solvent $\left(0.1 \%\right.$ formic acid, $\left.\mathrm{H}_{2} \mathrm{O}: \mathrm{MeCN}=50: 50 \mathrm{vol} / \mathrm{vol}\right)$ at a flow rate of $200 \mu \mathrm{l} / \mathrm{min}$. These analyses were performed in negative ion mode with a $5 \mathrm{kV}$ spray voltage. The mass range was set to $\mathrm{m} / \mathrm{z}, 70$ to 1,200 and the resolution to 60,000 (full width at half maximum at $\mathrm{m} / \mathrm{z}, 400$ ). Collision-induced dissociation fragmentation was carried out with a resolution of 15,000 , a normalized collision energy at 35\%, and an isolation width of $\mathrm{m} / z$ 3.0.

\section{Extraction and purification of agrocinopine $\mathbf{A}$.}

The method for extraction of agrocinopine A from IbACSexpressing tobacco was based on previous reports (Messens et al. 1986; Ryder et al. 1984) with some modifications. To detect agrocinopine A, thin-layer chromatography was carried out on Silica gel $60 \mathrm{~F}_{254}$ (Merck KGaA, Darmstadt, Germany), using a solvent system of n-propanol, acetic acid, and water (4:1:1, vol/ $\mathrm{vol} / \mathrm{vol}$ ) and using diphenylamine-aniline-acetone-phosphoric acid $(2 \mathrm{~g} / 2 \mathrm{ml} / 100 \mathrm{ml} / 15 \mathrm{ml})$ for chromogenic detection.

Fifty grams of $I b A C S$-expressing tobacco leaves were homogenized in $100 \mathrm{ml}$ of $70 \%$ ethanol for $10 \mathrm{~min}$, using an Osterizer (Oster, CA, U.S.A.). The homogenate was centrifuged at 4,000 $\times g$ for 10 min with an additional wash of the pellet with 100 $\mathrm{ml}$ of $70 \%$ ethanol. Fifteen milliliters of DOWEX 1X2 (Dow Chemical Co., Midland, MI, U.S.A.) (acetate form) was added to the collected supernatant solutions and was incubated to adsorb agrocinopine $\mathrm{A}$ for $16 \mathrm{~h}$ at $25^{\circ} \mathrm{C}$ with slow stirring. The resin $(10 \mathrm{ml})$ was collected and placed on top of a column (diameter $15 \mathrm{~mm}$, bed volume $40 \mathrm{ml}$ ) of DOWEX 1X2 (acetate form) and eluted $(1 \mathrm{ml} / \mathrm{min})$ with $0.2 \mathrm{M}$ pyridine and $0.1 \mathrm{M}$ acetic acid, $\mathrm{pH}$ 5.4. Fractions containing agrocinopine A were lyophilized. The sample was further purified by DEAESephadex A-25 (GE Healthcare, Uppasala, Sweden) chromatography (column diameter $12 \mathrm{~mm}$, bed volume $45 \mathrm{ml}$ ) with a linear gradient of $0.01 \mathrm{M}(150 \mathrm{ml})$ to $0.2 \mathrm{M}(150 \mathrm{ml})$ triethylammonium bicarbonate $(\mathrm{pH}$ 8.5) (Sigma-Aldrich Co., St. Louis) as elution buffer $(1 \mathrm{ml} / \mathrm{min})$. Fractions containing agrocinopine A were lyophilized. The sample, dissolved in a small volume of water, was loaded on a Bio-Gel P-2 Fine column (diameter $18 \mathrm{~mm}$, bed volume $80 \mathrm{ml}$ ) (Bio-Rad Laboratories. Inc., Hercules, CA, U.S.A.) and was eluted $(0.5 \mathrm{ml} / \mathrm{min})$ with $0.16 \mathrm{M}$ acetic acid. Fractions containing agrocinopine A were lyophilized.

\section{NMR analysis.}

NMR spectra were recorded on a Jeol ECA-600 spectrometer equipped with a field gradient accessory. Deuterium oxide (99.8 atom \%) (Kanto Chemical, Co., Inc., Tokyo) was used as solvent. Sodium 3-(trimethylsilyl)propionate-2,2,3,3- $d_{4}\left(\delta_{\mathrm{H}}\right.$ and $\delta_{\mathrm{C}}=0$ ) was used as an internal standard. The ${ }^{1} \mathrm{H}$ and ${ }^{13} \mathrm{C}$ NMR assignments were supported by two-dimensional NMR techniques including ${ }^{1} \mathrm{H}-{ }^{1} \mathrm{H}$ correlation spectroscopy, heteronuclear multiple quantum correlation, and heteronuclear multiple-bond correlation spectroscopy experiments. 


\section{Bioassay for agrocinopine activity.}

The biological activity of the IbACS1 product was detected by the method reported previously (Ellis and Murphy 1981). Samples containing agrocinopine A were separated and concentrated 10 times by HVPE, as described above. Each $6 \mu$ l of concentrated extract was spotted onto 5-mm filter paper discs. A. tumefaciens K1026, which produces agrocin 84 (Jones and Kerr 1989), was grown as a patch in the center of a plate of Stonier's medium (Stonier 1960) containing 1.2\% agar plus $10 \mathrm{mg}$ of thiamine per liter and $10 \mathrm{mg}$ of biotin per liter, for $48 \mathrm{~h}$. The producer strain was removed with a sterilized scalpel and the plate was then sterilized with chloroform vapor and was overlaid with the indicator strain (strain K293 for agrocinopine A or strain K923 for agrocinopine C) in soft buffered agar (0.7\% agar in 20 $\mathrm{mM}$ phosphate buffer, $\mathrm{pH}$ 6.8). Samples containing agrocinopine or controls were sterilized in chloroform vapor and were placed in the overlay agar. Plates were incubated at $28^{\circ} \mathrm{C}$ for up to 96 h. Agrocinopine A activity appeared as an extension of growth inhibition zones produced by agrocin 84 .

\section{Growth conditions of transgenic tobacco for $16 \mathrm{~S}$ rRNA sequencing and meta-transcriptome analysis.}

Transgenic tobacco seeds were surface sterilized with $2 \%$ hypochlorite solution, were germinated, and were grown on MurashigeSkoog agar plate for 2 weeks at $25^{\circ} \mathrm{C}$ under $16 \mathrm{~h}$ of light and $8 \mathrm{~h}$ of dark per day. Each seedling was transferred to $40 \mathrm{ml}$ of Murashige-Skoog agar and was grown for 3 weeks. They were planted in a 200-ml pot containing peat moss-based commercial soil mixture (Ace-baido) (SunAgro, Tokyo) and were grown for 2 weeks. Plants were transferred to fresh commercial soil mixture supplemented with $50 \mathrm{ml}$ (approximately 10\% vol/vol) of soils from an experimental field of Nagoya University (Togo, Aichi, Japan) at the bottom of a 500-ml pot and were grown for another 10 days at $25^{\circ} \mathrm{C}$ under $16 \mathrm{~h}$ of light and $8 \mathrm{~h}$ of dark per day.

\section{Isolation of bacterial strains and 16S rRNA sequencing.}

Roots of transgenic tobacco lines were washed with water. Root tissues $(200 \mathrm{mg}$ ) were ground and suspended in $1.2 \mathrm{ml}$ of sterile water, were then centrifuged at $1,000 \times g$. For isolation of bacterial strains, $2 \mu \mathrm{l}$ of the supernatant solution mixed with $100 \mu \mathrm{l}$ of water was spread onto a YM agar medium (Keele et al. 1969). The plates were incubated for 3 days at $28^{\circ} \mathrm{C}$. The V3-V4 regions of the bacterial 16S rRNA gene were amplified from randomly selected colonies by colony PCR, using EmeraldAmp PCR Master Mix (Takara Bio) with the primers 10F and 800R (Supplementary Table S5). PCR conditions were as follows: 35 cycles of $98^{\circ} \mathrm{C}$ for $10 \mathrm{~s}, 55^{\circ} \mathrm{C}$ for $30 \mathrm{~s}, 72^{\circ} \mathrm{C}$ for $1 \mathrm{~min}$.

For 16S rRNA amplicon sequencing for rhizosphere of tobacco, the water-washed root tissues were subjected to genomic DNA extraction using DNeasy Plant mini kit (Qiagen). Library construction and sequencing were performed at the Bioengineering Lab Co., Ltd (Sagamihara, Japan) as follows. The 16S rRNA V4 region of prokaryotes was amplified using the universal primers 314F and 805R (Supplementary Table S5) and was purified with AMPure XP beads (Beckman coulter, Brea, CA, U.S.A.). The peptide nucleic acids (PNAs), $3.75 \mu \mathrm{M}$ plastid PNA and $3.75 \mu \mathrm{M}$ mitochondrial PNA, were added to the reaction to prevent amplification of mitochondrial and chloroplast $16 \mathrm{~S}$ rRNA sequences. The libraries were constructed by the second round of amplification, using index primers followed by the purification, and were sequenced on an Illumina Miseq platform with a 300 bp paired-end protocol (Illumina, San Diego, CA, U.S.A.).

\section{RNA isolation and sequencing}

for meta-transcriptome analysis.

Total RNA was extracted from tobacco roots $(n=3)$ with the NucleoSpin RNA Plant kit (Takara Bio) according to manufac- turer instructions. rRNA was removed from $2 \mu \mathrm{g}$ of total RNA by using a RiboMinus plant kit and RiboMinus transcriptome isolation kit (bacteria) (Thermo Fisher Scientific, Waltham, MA, U.S.A.). Probes from both kits $(10 \mu \mathrm{l}$ of plant and $4 \mu \mathrm{l}$ of bacteria for each sample) were added to total RNA in hybridization buffer, were incubated at $75^{\circ} \mathrm{C}$ for $5 \mathrm{~min}$, and were cooled slowly to $37^{\circ} \mathrm{C}$ by placing the tubes in a $37^{\circ} \mathrm{C}$ water bath to simultaneously remove the plant and bacterial rRNA. rRNAdepleted RNA was purified according to manufacturer instructions. Libraries were prepared using a NEBNext Ultra II RNA library prep kit for Illumina (New England Biolabs, Ipswich, MA, U.S.A.), AMPure beads (Beckman Coulter, Fullerton, CA, U.S.A.), and NEBNext Multiplex Oligos for Illumina (New England Biolabs). The indexed libraries were sequenced (pairedend) on Illumina Nextseq 500 (Illumina) at Chubu University (Kasugai, Japan).

\section{Bioinformatic analysis.}

The 16S rRNA raw reads from Miseq sequencing were subjected to quality filtering by the Fastx toolkit (Schmieder and Edwards 2011). The processed reads were analyzed by using QIIME2 (Bolyen et al. 2019). Representative sequences were assigned at different taxonomic levels to the bacterial SILVA database with a $97 \%$ cutoff value. Sequences assigned as chloroplast and mitochondria were removed before downstream analysis.

Paired-end Illumina sequencing reads were assembled into a de novo transcriptome using the Oyster River Protocol (ORP) version 2.2.5 (MacManes 2018). The ORP was started by sequence read trimming using Trimmomatic version 0.38 . The remaining reads were then used to assemble transcriptomes using three different de novo assemblers, Trinity with a kmer length of 25 and without read normalization (Haas et al. 2013), rnaSPAdes with a kmer length of 55 and 75 (Chikhi and Medvedev 2014), and Shannon version 0.0.2 (Kannan et al. 2016), using a kmer length of 75 . Four unique assemblies produced by this process were merged by OrthoFuse. The quality of the de novo assembly was assessed using TransRate (SmithUnna et al. 2016). Functional annotation of the 78,144 de novo transcripts was done by using eggNOG-Mapper (Huerta-Cepas et al. 2017, 2019). The reads were mapped to de novo transcripts using bwa (Li 2013). The bwa output was processed by samtools to generate the read count table. Differential gene expression analysis was conducted in $\mathrm{R}$ using the tool from the Bioconductor R: edgeR package (Robinson et al. 2010).

\section{Genome sequencing of Leifsonia sp. strain LS1.}

Genomic DNA was extracted from Leifsonia sp. strain LS1 cells using a Genomic DNA purification kit (Promega, Madison, WI, U.S.A.), following manufacturer protocols. DNA library was prepared using a NEBNext Ultra II FS DNA Library Prep Kit (New England Biolabs), AMPure beads (Beckman Coulter), and NEBNext Multiplex Oligos for Illumina (New England Biolabs). The indexed library was sequenced on the NextSeq 500 sequencer (Illumina). Paired-end reads from genome sequencing of the strain LS1 $(28,752,817$ reads) with an average read length of $81 \mathrm{bp}$ were quality trimmed using the FASTQ preprocessing program fastp (Chen et al. 2018). De novo assembly was then performed using the SPAdes genome assembler version 3.12 (Bankevich et al. 2012) with two options ("-k 71" and "--careful"), which yielded 21 contigs with an $\mathrm{N}_{50}$ value of 375,735 bp and 566-fold mean coverage. Annotation of the contigs was performed using the DFAST version 1.0.8 pipeline (Tanizawa et al. 2018), which identified 4,464 putative coding sequences. The whole-genome distance between the strain LS1 and all other Leifsonia sp. genomes were calculated with fastANI (Jain et al. 2018). 
Inoculation of tobacco plant with Leifsonia sp. strain LS1.

Control (EV4) and IbACS1-expressing tobacco (Acs5) plants (approximately 5 weeks old) were inoculated with $100 \mu \mathrm{l}$ of Leifsonia sp. strain LS1 suspension $\left(1 \times 10^{9}\right.$ per milliliter $)$ by drip irrigation and were incubated for 3 weeks. After the incubation, total DNA was extracted from root tissues using DNeasy Plant mini kit (Qiagen), and this was used as template for qPCR with primer sets S2087290_F2 and R2 (Supplementary Table S5) to detect bacterial DNA. The quantity of bacterial DNA was determined with a calibration curve prepared using purified genomic DNA of Leifsonia sp. strain LS1. Conditions of qPCR were as described above.

\section{Test for the assimilation of agrocinopine A by Leifsonia sp. strain LS1.}

Leaf tissue of tobacco (EV4) or IbACS-expressing plants was ground in a sample tube and was centrifuged at $20,000 \times g$ at $20^{\circ} \mathrm{C}$. The supernatant solution was filter-sterilized using a Millex-GV syringe filter unit $(0.22 \mu \mathrm{m})$, and a $50-\mu \mathrm{l}$ aliquot was mixed with $1 \mu \mathrm{l}$ of bacterial suspension $\left(1 \times 10^{9}\right.$ per milliliter $)$. The mixture was incubated at $28^{\circ} \mathrm{C}$ for $24 \mathrm{~h}$ and was subjected to HVPE.

For the bacterial growth test, sterile EV4 leaf extract was diluted four times with water and was sterilized using a syringe filter unit. One micoliter of purified agrocinopine A $(250 \mathrm{ng} / \mu \mathrm{l}$, final concentration) was added to the leaf extract $(50 \mu \mathrm{l})$ for the agrocinopine A treatment. The mixture with or without agrocinopine A was inoculated with $1 \mu$ of bacterial suspension $(1 \times$ $10^{9}$ per milliliter), was incubated at $28^{\circ} \mathrm{C}$ for $24 \mathrm{~h}$, and was subjected to cell density (colony-forming units per milliliter) estimation according to the standard method.

\section{Data availability.}

The raw data for $16 \mathrm{~S}$ amplicon sequencing, metatranscriptome, and the genome sequence of Leifsonia sp. strain LS1 have been deposited in the DDBJ/EMBL/GenBank database under accession numbers DRA012625, DRA011841, and BPER01000001-21, respectively.

\section{ACKNOWLEDGMENTS}

We thank K. Okinawa Agricultural Research Center (NARO, Japan) for providing sweet potato cultivars Hanaranman and White Star. We also thank I. Mitsuhara (Institute of Agrobiological Sciences, NARO, Japan) for providing the $\mathrm{pEl} 2 \Omega$ vector, K. Saeki (Nara Women's University, Japan) for providing E. coli S17-1, and Y. Tahara (Nagoya University, Japan) for providing agricultural field soils.

\section{LITERATURE CITED}

Anderson, J. A., Ellsworth, P. C., Faria, J. C., Head, G. P., Owen, M. D. K., Pilcher, C. D., Shelton, A. M., and Meissle, M. 2019. Genetically engineered crops: Importance of diversified integrated pest management for agricultural sustainability. Front. Bioeng. Biotechnol. 7:24.

Bankevich, A., Nurk, S., Antipov, D., Gurevich, A. A., Dvorkin, M., Kulikov, A. S., Lesin, V. M., Nikolenko, S. I., Pham, S., Prjibelski, A. D., Pyshkin, A. V., Sirotkin, A. V., Vyahhi, N., Tesler, G., Alekseyev, M. A., and Pevzner, P. A. 2012. SPAdes: A new genome assembly algorithm and its applications to single-cell sequencing. J. Comput. Biol. 19:455-477.

Barco, R. A., Garrity, G. M., Scott, J. J., Amend, J. P., Nealson, K. H., and Emerson, D. 2020. A genus definition for Bacteria and Archaea based on a standard genome relatedness index. MBio 11:e02475-19.

Beauchamp, C. J., Chilton, W. S., Dion, P., and Antoun, H. 1990. Fungal catabolism of crown gall opines. Appl. Environ. Microbiol. 56:150-155.

Bolyen, E., Rideout, J. R., Dillon, M. R., Bokulich, N. A., Abnet, C. C., Al-Ghalith, G. A., Alexander, H., Alm, E. J., Arumugam, M., Asnicar, F., Bai, Y., Bisanz, J. E., Bittinger, K., Brejnrod, A., Brislawn, C. J., Brown, C. T., Callahan, B. J., Caraballo-Rodríguez, A. M., Chase, J., Cope, E. K., Da Silva, R., Diener, C., Dorrestein, P. C., Douglas, G. M., Durall, D. M., Duvallet, C., Edwardson, C. F., Ernst, M., Estaki, M., Fouquier, J., Gauglitz, J. M., Gibbons, S. M., Gibson,
D. L., Gonzalez, A., Gorlick, K., Guo, J., Hillmann, B., Holmes, S., Holste, H., Huttenhower, C., Huttley, G. A., Janssen, S., Jarmusch, A. K., Jiang, L., Kaehler, B. D., Kang, K. B., Keefe, C. R., Keim, P., Kelley, S. T., Knights, D., Koester, I., Kosciolek, T., Kreps, J., Langille, M. G. I., Lee, J., Ley, R., Liu, Y. X., Loftfield, E., Lozupone, C., Maher, M., Marotz, C., Martin, B. D., McDonald, D., McIver, L. J., Melnik, A. V., Metcalf, J. L., Morgan, S. C., Morton, J. T., Naimey, A. T., Navas-Molina, J. A., Nothias, L. F., Orchanian, S. B., Pearson, T., Peoples, S. L., Petras, D., Preuss, M. L., Pruesse, E., Rasmussen, L. B., Rivers, A., Robeson, M. S., 2nd, Rosenthal, P., Segata, N., Shaffer, M., Shiffer, A., Sinha, R., Song, S. J., Spear, J. R., Swafford, A. D., Thompson, L. R., Torres, P. J., Trinh, P., Tripathi, A., Turnbaugh, P. J., Ul-Hasan, S., van der Hooft, J. J. J., Vargas, F., Vázquez-Baeza, Y., Vogtmann, E., von Hippel, M., Walters, W., Wan, Y., Wang, M., Warren, J., Weber, K. C., Williamson, C. H. D., Willis, A. D., Xu, Z. Z., Zaneveld, J. R., Zhang, Y., Zhu, Q., Knight, R., and Caporaso, J. G. 2019. Reproducible, interactive, scalable and extensible microbiome data science using QIIME 2. Nat. Biotechnol. 37:852-857.

Chen, S., Zhou, Y., Chen, Y., and Gu, J. 2018. fastp: An ultra-fast all-inone FASTQ preprocessor. Bioinformatics 34:i884-i890.

Chikhi, R., and Medvedev, P. 2014. Informed and automated k-mer size selection for genome assembly. Bioinformatics 30:31-37.

Duke, S. O. 2015. Perspectives on transgenic, herbicide-resistant crops in the United States almost 20 years after introduction. Pest Manag. Sci. 71:652-657.

Ellis, J. G., and Murphy, P. J. 1981. Four new opines from crown gall tumors - their detection and properties. Mol. Gen. Genet. 181:36-43.

Guyon, P., Chilton, M. D., Petit, A., and Tempé, J. 1980. Agropine in "null-type" crown gall tumors: Evidence for generality of the opine concept. Proc. Natl. Acad. Sci. U.S.A. 77:2693-2697.

Guyon, P., Petit, A., Tempé, J., and Dessaux, Y. 1993. Transformed plants producing opines specifically promote growth of opinedegrading agrobacteria. Mol. Plant-Microbe Interact. 6:92-98.

Haas, B. J., Papanicolaou, A., Yassour, M., Grabherr, M., Blood, P. D., Bowden, J., Couger, M. B., Eccles, D., Li, B., Lieber, M., MacManes, M. D., Ott, M., Orvis, J., Pochet, N., Strozzi, F., Weeks, N., Westerman, R., William, T., Dewey, C. N., Henschel, R., LeDuc, R. D., Friedman, N., and Regev, A. 2013. De novo transcript sequence reconstruction from RNA-seq using the Trinity platform for reference generation and analysis. Nat. Protoc. 8:1494-1512.

Hayman, G. T., Beck von Bodman, S., Kim, H., Jiang, P., and Farrand, S. K. 1993. Genetic analysis of the agrocinopine catabolic region of Agrobacterium tumefaciens $\mathrm{Ti}$ plasmid pTiC58, which encodes genes required for opine and agrocin 84 transport. J. Bacteriol. 175: 5575-5584.

Hayman, G. T., and Farrand, S. K. 1988. Characterization and mapping of the agrocinopine-agrocin 84 locus on the nopaline Ti plasmid pTiC58. J. Bacteriol. 170:1759-1767.

Hirakawa, H., Okada, Y., Tabuchi, H., Shirasawa, K., Watanabe, A., Tsuruoka, H., Minami, C., Nakayama, S., Sasamoto, S., Kohara, M., Kishida, Y., Fujishiro, T., Kato, M., Nanri, K., Komaki, A., Yoshinaga, M., Takahata, Y., Tanaka, M., Tabata, S., and Isobe, S. N. 2015. Survey of genome sequences in a wild sweet potato, Ipomoea trifida (H. B. K.) G. Don. DNA Res. 22:171-179.

Huerta-Cepas, J., Forslund, K., Coelho, L. P., Szklarczyk, D., Jensen, L. J., von Mering, C., and Bork, P. 2017. Fast genome-wide functiona annotation through orthology assignment by eggNOG-Mapper. Mol. Biol. Evol. 34:2115-2122.

Huerta-Cepas, J., Szklarczyk, D., Heller, D., Hernández-Plaza, A., Forslund, S. K., Cook, H., Mende, D. R., Letunic, I., Rattei, T., Jensen, L. J., von Mering, C., and Bork, P. 2019. eggNOG 5.0: A hierarchical, functionally and phylogenetically annotated orthology resource based on 5090 organisms and 2502 viruses. Nucleic Acids Res. 47 (D1): D309-D314.

Jain, C., Rodriguez-R, L. M., Phillippy, A. M., Konstantinidis, K. T., and Aluru, S. 2018. High throughput ANI analysis of $90 \mathrm{~K}$ prokaryotic genomes reveals clear species boundaries. Nat. Commun. 9:5114.

Jones, D. A., and Kerr, A. 1989. Agrobacterium radiobacter strain K1026, a genetically engineered derivative of strain K84, for biological control of crown gall. Plant Dis. 73:15-18.

Joos, H., Inzé, D., Caplan, A., Sormann, M., Van Montagu, M., and Schell, J. 1983. Genetic analysis of T-DNA transcripts in nopaline crown galls. Cell 32:1057-1067.

Kannan, S., Hui, J., Mazooji, K., Pachter, L., and Tse, D. 2016. Shannon: An information-optimal de novo RNA-Seq assembler. BioRxiv 039230.

Keele, B. B., Jr., Hamilton, P. B., and Elkan, G. H. 1969. Glucose catabolism in Rhizobium japonicum. J. Bacteriol. 97:1184-1191. 
Kim, H., and Farrand, S. K. 1997. Characterization of the acc operon from the nopaline-type Ti plasmid pTiC58, which encodes utilization of agrocinopines A and B and susceptibility to agrocin 84. J. Bacteriol. 179:7559-7572

Konstantinidis, K. T., and Tiedje, J. M. 2005. Genomic insights that advance the species definition for prokaryotes. Proc. Natl. Acad. Sci. U.S.A. 102:2567-2572.

Kovacova, V., Zluvova, J., Janousek, B., Talianova, M., and Vyskot, B. 2014. The evolutionary fate of the horizontally transferred agrobacterial mikimopine synthase gene in the genera Nicotiana and Linaria. PLoS One 9:e113872.

Kyndt, T., Quispe, D., Zhai, H., Jarret, R., Ghislain, M., Liu, Q., Gheysen, G., and Kreuze, J. F. 2015. The genome of cultivated sweet potato contains Agrobacterium T-DNAs with expressed genes: An example of a naturally transgenic food crop. Proc. Natl. Acad. Sci. U.S.A. 112: 5844-5849.

Lacroix, B., and Citovsky, V. 2019. Pathways of DNA transfer to plants from Agrobacterium tumefaciens and related bacterial species. Annu. Rev. Phytopathol. 57:231-251.

Lang, J., Vigouroux, A., Planamente, S., El Sahili, A., Blin, P., AumontNicaise, M., Dessaux, Y., Moréra, S., and Faure, D. 2014. Agrobacterium uses a unique ligand-binding mode for trapping opines and acquiring a competitive advantage in the niche construction on plant host. PLoS Pathog. 10:e100444s4.

Li, H. 2013. Aligning sequence reads, clone sequences and assembly contigs with BWA-MEM. arXiv 3:13033997.

MacManes, M. D. 2018. The Oyster River Protocol: A multi-assembler and kmer approach for de novo transcriptome assembly. PeerJ 6: e5428.

Matveeva, T. V., and Otten, L. 2019. Widespread occurrence of natural genetic transformation of plants by Agrobacterium. Plant Mol. Biol. 101:415-437.

Matveeva, T. V., and Sokornova, S. V. 2017. Biological traits of naturally transgenic plants and their evolutional roles. Russ. J. Plant Physiol. 64:635-648.

Messens, E., Lenaerts, A., Montagu, M. V., De Bruyn, A., Jans, A. W. H., and Binst, G. V. 1986. ${ }^{1} \mathrm{H}$ and ${ }^{31} \mathrm{P}$ NMR spectroscopy of agrocinopine. J. Carbohydr. Chem. 5:683-699.

Moore, L. W., Chilton, W. S., and Canfield, M. L. 1997. Diversity of opines and opine-catabolizing bacteria isolated from naturally occurring crown gall tumors. Appl. Environ. Microbiol. 63:201-207.

Ochman, H., Lawrence, J. G., and Groisman, E. A. 2000. Lateral gene transfer and the nature of bacterial innovation. Nature 405:299-304.

Oger, P., and Farrand, S. K. 2001. Co-evolution of the agrocinopine opines and the agrocinopine-mediated control of TraR, the quorumsensing activator of the Ti plasmid conjugation system. Mol. Microbiol. 41:1173-1185

Oger, P., Petit, A., and Dessaux, Y. 1997. Genetically engineered plants producing opines alter their biological environment. Nat. Biotechnol. $15: 369-372$.
Ohshima, M., Mitsuhara, I., Okamoto, M., Sawano, S., Nishiyama, K. Kaku, H., Natori, S., and Ohashi, Y. 1999. Enhanced resistance to bacterial diseases of transgenic tobacco plants overexpressing sarcotoxin IA, a bactericidal peptide of insect. J. Biochem. 125:431-435.

Ohtsubo, N., Mitsuhara, I., Koga, M., Seo, S., and Ohashi, Y. 1999. Ethylene promotes the necrotic lesion formation and basic PR gene expression in TMV-infected tobacco. Plant Cell Physiol. 40:808-817.

Quispe-Huamanquispe, D. G., Gheysen, G., Yang, J., Jarret, R., Rossel, G., and Kreuze, J. F. 2019. The horizontal gene transfer of Agrobacterium T-DNAs into the series Batatas (Genus Ipomoea) genome is not confined to hexaploid sweetpotato. Sci. Rep. 9:12584.

Robinson, M. D., McCarthy, D. J., and Smyth, G. K. 2010. edgeR: A Bioconductor package for differential expression analysis of digital gene expression data. Bioinformatics 26:139-140.

Ryder, M. H., Tate, M. E., and Jones, G. P. 1984. Agrocinopine A, a tumor-inducing plasmid-coded enzyme product, is a phosphodiester of sucrose and L-arabinose. J. Biol. Chem. 259:9704-9710.

Savka, M. A., and Farrand, S. K. 1997. Modification of rhizobacterial populations by engineering bacterium utilization of a novel plantproduced resource. Nat. Biotechnol. 15:363-368.

Schmidt, G. W., and Delaney, S. K. 2010. Stable internal reference genes for normalization of real-time RT-PCR in tobacco (Nicotiana tabacum) during development and abiotic stress. Mol. Genet. Genomics 283:233-241.

Schmieder, R., and Edwards, R. 2011. Quality control and preprocessing of metagenomic datasets. Bioinformatics 27:863-864.

Smith-Unna, R., Boursnell, C., Patro, R., Hibberd, J. M., and Kelly, S. 2016. TransRate: Reference-free quality assessment of de novo transcriptome assemblies. Genome Res. 26:1134-1144.

Stonier, T. 1960. Agrobacterium tumefaciens Conn. II. Production of an antibiotic substance. J. Bacteriol. 79:889-898.

Suzuki, K., Hattori, Y., Uraji, M., Ohta, N., Iwata, K., Murata, K., Kato, A., and Yoshida, K. 2000. Complete nucleotide sequence of a plant tumor-inducing Ti plasmid. Gene 242:331-336.

Suzuki, K., Yamashita, I., and Tanaka, N. 2002. Tobacco plants were transformed by Agrobacterium rhizogenes infection during their evolution. Plant J. 32:775-787.

Tanizawa, Y., Fujisawa, T., and Nakamura, Y. 2018. DFAST: A flexible prokaryotic genome annotation pipeline for faster genome publication. Bioinformatics 34:1037-1039.

Tremblay, G., Lambert, R., Lebeuf, H., and Dion, P. 1987. Isolation of bacteria from soil and crown-gall tumors on the basis of their capacity for opine utilization. Phytoprotection 68:35-42.

Trevelyan, W. E., Procter, D. P., and Harrison, J. S. 1950. Detection of sugars on paper chromatograms. Nature 166:444-445.

White, F. F., Garfinkel, D. J., Huffman, G. A., Gordon, M. P., and Nester, E. W. 1983. Sequence homologous to Agrobacterium rhizogenes T-DNA in the genomes of uninfected plants. Nature 301:348-350.

Ye, X., Al-Babili, S., Klöti, A., Zhang, J., Lucca, P., Beyer, P., and Potrykus, I. 2000. Engineering the provitamin A (beta-carotene) biosynthetic pathway into (carotenoid-free) rice endosperm. Science 287:303-305. 